\title{
Role of Helicobacters in Neuropsychiatric Disease: A Systematic Review in Idiopathic Parkinsonism
}

\author{
Rosalind M. Tucker 1,2, Aisha D. Augustin 1,2 Bu' Hussain Hayee ${ }^{3}$, Ingvar Bjarnason ${ }^{3}$, \\ David Taylor ${ }^{1,2}$, Clive Weller ${ }^{1}$, André Charlett ${ }^{1,4}$, Sylvia M. Dobbs ${ }^{1,2,3, *}$ and R. John Dobbs ${ }^{1,2,3}$ \\ 1 Pharmaceutical Sciences, King's College, London SE1 9NH, UK; Rosalind.Tucker@kcl.ac.uk (R.M.T.); \\ Aisha.Augustin@kcl.ac.uk (A.D.A.); David.Taylor@slam.nhs.uk (D.T.); Clive.Weller@kcl.ac.uk (C.W.); \\ Andre.Charlett@phe.gov.uk (A.C.); John.Dobbs@kcl.ac.uk (R.J.D.) \\ 2 The Maudsley Hospital, London SE5 8AZ, UK \\ 3 Gastroenterology, King's College Hospital, London SE5 9RS, UK; \\ B.Hayee@nhs.net (B.H.H.); IngvarBjarnason@mac.com (I.B.) \\ 4 Statistics, Modelling and Economics, National Infection Service, Public Health England, \\ London NW9 5EQ, UK \\ * Correspondence: Sylvia.Dobbs@kcl.ac.uk
}

Received: 14 June 2020; Accepted: 5 July 2020; Published: 8 July 2020

check for updates

\begin{abstract}
Interest in an aetiopathogenic role for Helicobacter in neuropsychiatric diseases started with idiopathic parkinsonism (IP), where the cardinal signs can be assessed objectively. This systematic review, using an EMBASE database search, addresses Oxford Centre for Evidence-Based Medicine based questions on the inter-relationship of Helicobacter and IP, the benefits of eradicating Helicobacter in IP and the outcome of not treating. The search strategy was based on Preferred Reporting Items for Systematic Reviews and Meta-Analyses guidelines: 21 of 204 articles met the inclusion criteria. The results show that the assumption that any benefit of Helicobacter eradication results from improved levodopa bioavailability is unjustified. The inter-relationship between Helicobacter and IP is well-established. H. pylori virulence markers (associated with autoimmunity and immune tolerance) influence the risk, severity and progression of IP. The birth cohort effect for virulence marker antibodies, seen in controls, is obliterated in IP, suggesting causality. Successful H. pylori eradication in IP is disease-modifying (even in anti-parkinsonian treatment-naïve patients) but not preventive. Hypokinesia regresses with eradication and overall motor severity lessens. Eradication may influence gastrointestinal microbiota adversely, unlocking the next stage in the natural history, the development of rigidity. Failed eradication worsens hypokinesia, as does the presence/persistence of $H$. pylori at molecular level only. Adequate prognostic assessment of the consequences of not treating Helicobacter, for IP, is prevented by a short follow-up. We conclude that Helicobacter is a pathophysiological driver of IP.
\end{abstract}

Keywords: Helicobacter pylori; virulence markers; non-Helicobacter pylori Helicobacters; eradication; Parkinson's disease; aetiopathogenesis; brady/hypokinesia; rigidity

\section{Introduction}

Helicobacter pylori is one of the most common human pathogens, estimated to infect approximately 4.4 billion people worldwide, $45-80 \%$ of whom remain asymptomatic $[1,2]$. The principal site of infection is the gastric mucosal surface, where the organism is protected from acid by mucus and the generation of ammonia by urease [3]. Warren and Marshall first isolated these curved bacilli from patients with chronic gastritis (1983) and with peptic ulcer (1984) [4,5]. Helicobacter pylori is now the established primary cause of chronic gastritis, peptic ulcers, non-cardia gastric carcinoma and 
gastric mucosa-associated lymphoid tissue (MALT) lymphoma. Treating infection almost halves the incidence of non-cardia carcinoma [6]. Eradication is the treatment of choice for MALT lymphoma when confined to the stomach or with peri-gastric lymph node involvement [7]. Colonisation has also been reported in the mouth and liver [8-10]. The significance of H. pylori extends beyond the stomach [11-20]. Some conditions (iron and B12 deficiencies) are direct consequences of gastric infection and subsequent atrophy. Others appear to be truly extra-gastric. For example, H. pylori eradication has a well-established therapeutic effect on idiopathic thrombocytopenic purpura [16]. Candidature in Sjögren's syndrome, atherosclerosis, migraine and rosacea rests largely on association $[17,18,21]$.

It is widely recognised that $H$. pylori infection, especially strains with the pathogenicity marker cytotoxin-associated gene product (CagA), is associated inversely with Barratt's oesophagus [22]. There are other interesting negative relationships, in keeping with the maintenance of immune homeostasis by H. pylori infection [23], in chronic immune-mediated disorders such as asthma, rheumatoid arthritis and inflammatory bowel disease [24]. Moreover, the treatment of $H$. pylori appears to increase the incidence of inflammatory bowel disease. A registry database in Taiwan showed that, in peptic ulcer disease, H. pylori eradication carried an increased risk of developing autoimmunity or inflammatory bowel disease compared with no eradication (assumed to represent no H. pylori infection since most would have been tested) [24].

What is the evidence for Helicobacter having a role in neuropsychiatric disease? From 2000, we identified, using the EMBASE database, 70 relevant papers linking neuropsychiatric diseases (idiopathic parkinsonism (IP), Alzheimer's disease, mild cognitive impairment, affect disorders, schizophrenia/psychosis) to Helicobacter. Prior to the discovery of Helicobacter pylori-associated gastritis, an excess of concurrent (1961) and previously documented (1965) peptic ulcers was observed in IP [25,26]. Szabo proposed that an infectious agent was involved in both (1979) [27], before the name of that agent could simply be added [28]. Dopaminergic agonists can prevent duodenal ulcer relapse [29] but it is unknown whether this is due to Helicobacter suppression. The epidemiological fit of H. pylori with IP includes ubiquity, insidiousness, familial aggregation, immunological manifestations, linkage with drinking water sources [30] and associations with rosacea and migraine [17,18,31-33]. Most H. pylori infections are transmitted within a closely shared environment, from parent or sibling to infant [34], and then they persist. Indeed, in 1999, Charlett et al. reported that both IP patients and their siblings were three times more likely than controls to be seropositive for the H. pylori anti-urease antibody and that siblings were quantifiably "down-the-way" towards IP on objective measures of its facets [35]. Our aim here is to examine systematically the subsequent evidence defining the role of Helicobacter in IP.

\section{Methods}

\subsection{Search Strategy}

This systematic review was conducted and reported in line with the "Preferred Reporting Items for Systematic Reviews and Meta-Analyses" (PRISMA) guidelines [36]. The search strategy was based on the "Population, Intervention, Comparison, Outcome" (PICO) framework: $\mathrm{P}=$ people with or without IP; I = anti-Helicobacter treatment course; $\mathrm{C}=$ comparison of IP severity/manifestations pre- and post-Helicobacter eradication, and by Helicobacter-status according to IP-status or vice versa; $\mathrm{O}=$ severity/manifestations or status frequency.

The literature search was conducted using the Ovid EMBASE online database, with restriction to papers published between 2000 and 2019 in peer-reviewed scientific journals in, or with translation to, English. A systematic search combined two groups of keywords, one for the microbial insult (Helicobacter infection, Helicobacter (genus) or Helicobacter pylori) and the other for the IP target (Parkinson's, Parkinson disease, idiopathic parkinsonism). We adopt the term "idiopathic parkinsonism" to refer to the target syndrome, with its variable combination of defined signs, in the absence of a recognised cause. Included were randomised or open Helicobacter eradication trials and cross-sectional observational (cohort 
or case-control) studies. Excluded from the systematic review (but not from the framing narrative reviews) were case reports, reviews and meta-analyses.

\subsection{Subjective and Objective Measures of Idiopathic Parkinsonism}

Outcomes for IP included global scores with particular reference to motor severity (e.g., Unified Parkinson's Disease Rating Scale (UPDRS) Part III-motor section [37], Webster scale) [38]); disability Parkinson's Disease Questionnaire (PDQ39) [39]; functional staging (Hoehn and Yahr) [40]; independence in activities of daily living (Schwab and England) [41]; or change in maintenance requirements for symptomatic treatment of IP. Regarding the clinical manifestations of IP, reference was made to motor subscores in UPRDS-III, but preference was given to the objective assessment of individual cardinal signs on a continuous scale (for example, mean stride length at free walking speed is a measure of hypokinesia, with high sensitivity to and specificity for IP [42]). Immune manifestations were included in the outcomes of note. We also included motor complications of levodopa therapy (UPDRS-IV) [37] and levodopa pharmacokinetics, since the effects of Helicobacter eradication might be ascribed to changes in levodopa bioavailability.

Outcomes with respect to the microbial insult included evidence of current status (from gastric biopsy, urea breath test (UBT), stool antigen) or past/concurrent status (eradication history, serology). Quantification of the antibody titre or pathogenicity marker profile was used where available.

\subsection{Study Selection}

Figure 1 summarises the article selection process from search results, through screening and compliance with eligibility criteria, to inclusion. Two reviewers (R.M.T. and A.D.A.) scanned the search results independently. First, the titles and abstracts of the search results were checked, and then the full texts of possibly relevant articles were checked. After each step, the reviewers held a consensus meeting to discuss discrepancies in the selection. A third reviewer (R.J.D.) assessed any ambiguous selections.

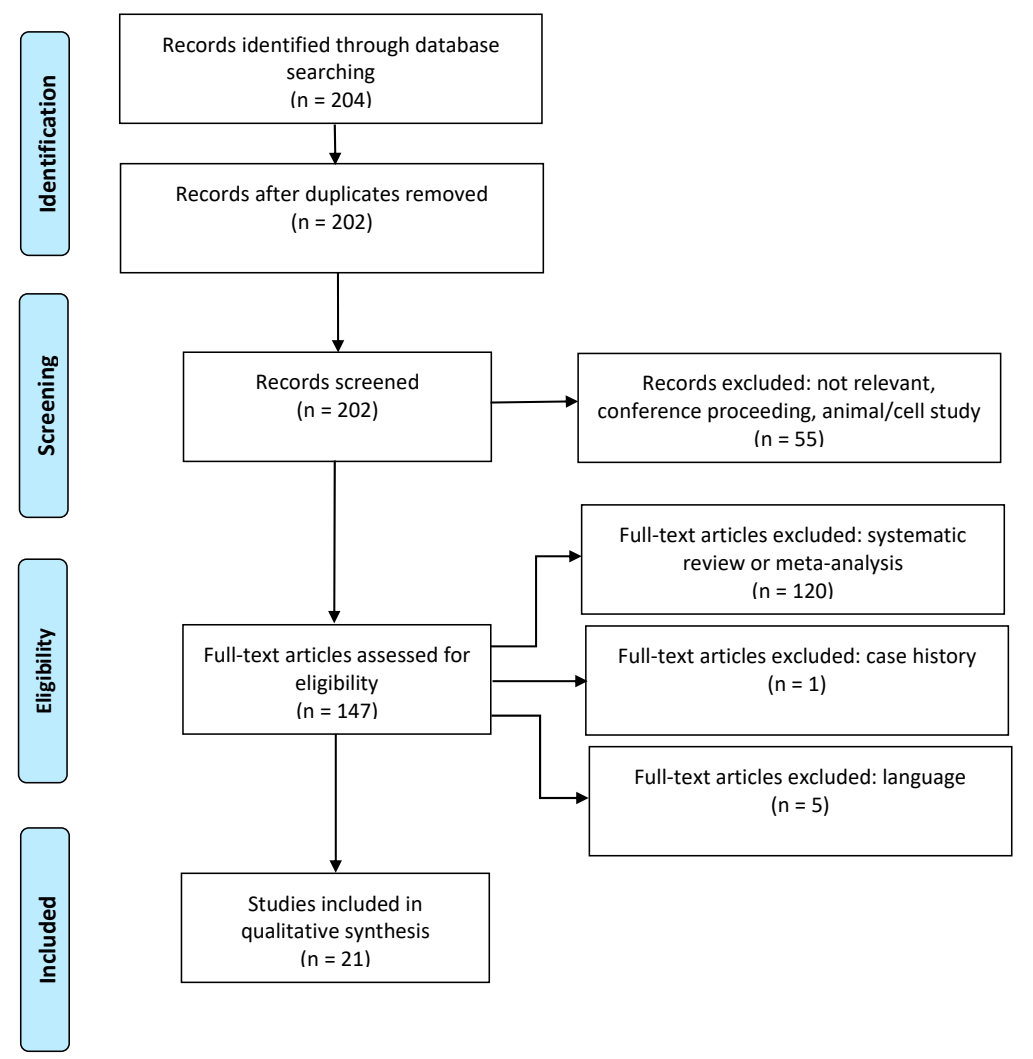

Figure 1. Preferred reporting for systematic review and meta-analysis (PRISMA) flow chart. 


\subsection{Data Extraction and Questions Addressed}

The following information was extracted from each included article (Tables 1-5): (i) citation; (ii) type of study: eradication trial, randomised (active eradication versus an alternative treatment such as placebo) or open, or cross-sectional comparison without or with retrospective/prospective data; (iii) cohort size; (iv) methodology for Helicobacter ascertainment and any confirmation of its eradication; (v) clinical outcome(s); and (vi) country where the study was performed.

The Oxford Centre for Evidence-Based Medicine (OCEBM) questions [43] that were addressed using the cumulative stratified evidence were as follows: (i) Does this intervention help (treatment benefits)?, (ii) What will happen if we do not add a therapy (prognosis)?, (iii) How common is the problem?

\subsection{Risk of Bias}

The methodological quality of each included study was assessed by two assessors (R.M.T., A.D.A), followed by a consensus meeting and a consultation with a senior researcher (R.J.D.) for overview. The Cochrane risk of bias assessment tool was applied to the randomised controlled trials [44].

\section{Results}

\subsection{Search Results}

The search returned 204 research titles (Figure 1). Excluded were two as duplicates, 18 as irrelevant, 33 as conference abstracts, four as animal studies, 120 as reviews or metanalysis, one as a case history and five on language. The remaining 21 original articles met the inclusion criteria, one being published as interim [45] and final [46] study reports. Studies were from Europe (11/20), East (4/20) and South East (3/20) Asia and the Middle East (2/20).

\subsection{Study Characteristics}

Tables 1 and 2 summarise the characteristics of the six trials on the effect of Helicobacter eradication on the global severity of IP or its cardinal signs.

Table 1 gives the two randomized controlled trials (RCTs) [45-47]. In both, active treatment was a 7-day course of triple therapy with two antimicrobials and a proton pump inhibitor. Both studies used endoscopic biopsy diagnosis of $H$. pylori infection. In the first [45,46], the choice of antimicrobials took into account in vitro sensitivities, whereas a fixed regimen was used in the second [47]. Only the former used molecular microbiology to detect/exclude low infection load. The comparator arm in the first trial $[45,46]$ received placebo, dummy tablets without active ingredient being manufactured for the antimicrobials exhibited and for the proton pump inhibitor. The comparator in the second [47] was a 15-day course of allopurinol (as an antioxidant), with a placebo balance aimed at giving the same number of tablets per day in both treatment arms. In the first trial $[45,46]$, use of the short $(0.75-1.5 \mathrm{~h})$ elimination, half-time $\left(\mathrm{t} \frac{1}{2}\right)$, anti-parkinsonian drug, levodopa, was an exclusion, in order to avoid confounding by drug-induced fluctuations. In the second [47], in contrast, having motor fluctuations on levodopa monotherapy was an inclusion criterion.

Recruitment in the first trial [45] was halted when marked deterioration in hypokinesia was noted with failed eradication. Despite this, the size of effect at 1 year, on intention-to-treat analysis, was more than 1.5 times that used in the original sample size calculation. The final report [46] allowed the inclusion of participants who had not reached de-blinding at the time of the interim analysis and follow-up for 2 years after the blinded phase. This included cross-over to open-active eradication in those with persistent $H$. pylori infection after placebo. Protocol analysis of proven eradication refines the contrast. In the second trial [47], there was no sample size calculation to achieve a pre-determined size of effect, but the sample size was slightly larger than in the first RCT. Follow-up was for 3 months [47]. Additional contrast of failed with successful eradication was made in both studies. 
Table 2 shows four non-randomised trials. One had fixed-order cross-over from placebo to active eradication, with follow-up for 2 weeks in each phase [48]. Three were open eradication trials, with follow-up for 3 months [49,50] or 1 year [51]. Three used isotope-labelled urea breath tests (UBT) [49-51], the other serology. In the first two open trials, motor fluctuations attributed to levodopa were an inclusion criterion [48,49]. All participants were receiving levodopa in the third [50], some in the fourth [51].

Table 3 includes information from two of the above [49,50] plus six additional studies [52-57] which provide cross-sectional observational analyses of the effect of Helicobacter-status on the severity of IP and/or its cardinal signs. Half tested for current infection by UBT [49,50,55] or stool antigen [53], the rest used serology. Seven studies included people taking levodopa [49,50,52-56], motor fluctuations being an inclusion criterion in two $[53,56]$. There was no information on levodopa in the eighth study [57].

Table 4 lists studies of the effect of Helicobacter-status on outcomes other than global motor severity of IP and measurement of its facets [58-61].

Table 5 includes information from five of the above $[52,54,56,57,60]$ plus four additional studies [62-65] on the comparative incidence or frequency of Helicobacter according to IP-status or, conversely, of IP according to Helicobacter-status. Two studies use analysis of National Registry data. One [63] defines populations by IP-status (tracing retrospectively for a Helicobacter eradication course), the other [65] by Helicobacter-status (tracing prospectively for IP medication). Two studies [52,62] address the obliteration of birth cohort effects (i.e. the increasing frequency of Helicobacter-seropositivity with age) in diagnosed IP. Four studies $[54,56,57,60]$ report the relative frequency of Helicobacter in IP (by serology in 3, UBT in one) compared with a group of controls. In one study [60] using UBT, the controls were IP patients' spouses, ignoring the possibility of Helicobacter transmission in the home environment. One study [64] addressed the frequency of non-Helicobacter pylori Helicobacter (NHPH) infection (detected by PCR on endoscopic biopsy) relative to that of $H$. pylori, according to IP-status. Lack of IP-status information in the large control group should have militated against finding a difference in frequency. 
Table 1. Randomised controlled trials of effect of H. pylori eradication on severity of, and hypokinesia in, idiopathic parkinsonism.

\begin{tabular}{|c|c|c|c|c|c|c|}
\hline Study & $\begin{array}{c}\text { Ascertainment of } \\
\text { Helicobacter } \\
\text { Positivity }\end{array}$ & Interventions & $\begin{array}{c}\text { Number } \\
\text { Participants } \\
\text { (Levodopa-Status) }\end{array}$ & $\begin{array}{c}\text { Primary Relevant } \\
\text { Outcome } \\
\text { Measure }\end{array}$ & $\begin{array}{l}\text { Duration Blinded } \\
\text { Phase (Confirmation } \\
\text { Eradication) }\end{array}$ & Findings \\
\hline $\begin{array}{c}\text { Bjarnason et al. * } \\
(2005) \\
\text { Dobbs et al. }{ }^{* *}(2010) \\
{[45,46]}\end{array}$ & $\begin{array}{l}\mathrm{UBT}^{+} \text {endoscopic } \\
\text { biopsy } \\
\text { (histopathology, } \\
\text { culture and } \\
\text { sensitivities, PCR) }\end{array}$ & $\begin{array}{l}\text { 1-week triple therapy, } \\
++ \text { according to in vitro } \\
\text { sensitivities/suspected } \\
\text { intolerance, } \\
\text { or matched placebo } \\
\text { (tablets/capsules } \\
\text { without active } \\
\text { moiety) }\end{array}$ & $\begin{array}{l}\text { 30: } 14 \text { active, } \\
\text { 16 placebo } \\
\text { (no levodopa) }\end{array}$ & $\begin{array}{c}\text { Mean stride } \\
\text { length at free } \\
\text { walking speed }\end{array}$ & $\begin{array}{c}\text { De-blinding at } \\
54 \text { weeks (UBT in all } \\
\text { at } 1 \text { year, with repeat } \\
\text { biopsy after active) }\end{array}$ & $\begin{array}{l}\text { Intention to treat analysis: effect } \\
\text { equivalent to } 1.02 \text { times } \\
\text { between-subject SD, }{ }^{\#} \text { whereas } \\
\text { study designed to detect } 0.75 \\
\text { (SD) with } n=56 \text {. I } \\
\text { Protocol analysis (excluding two } \\
\text { eradication failures of } \\
\text { blinded-active): stride length } \\
\text { (time trend in 6-weekly } \\
\text { measurements) improved on } \\
\text { active by } 7.3 \mathrm{~cm} / \text { year cf placebo. } \\
\text { Effect similar whether receiving } \\
\text { stable background (long t } \frac{1}{2} \text { ) } \\
\text { anti-parkinsonian medication or } \\
\text { treatment-naïve. }\end{array}$ \\
\hline $\begin{array}{l}\text { Pierantozzi et al. } \\
\text { (2006) [47] }\end{array}$ & $\begin{array}{l}\text { Serology (ELISA), } \\
\text { stool antigen, } \\
\text { endoscopic biopsy } \\
\text { (rapid urease test, } \\
\text { histopathology, } \\
\text { culture) }\end{array}$ & $\begin{array}{l}\text { 1-week fixed triple } \\
\text { therapy, }{ }^{+} \text {or } \\
\text { allopurinol } 100 \mathrm{mg} \\
\text { twice daily for } \\
15 \text { days (treatments } \\
\text { said to be balanced by } \\
\text { placebo to equalise } \\
\text { number pills/day and } \\
\text { course duration) }\end{array}$ & $\begin{array}{c}\text { 36: } 19 \text { active } \\
17 \text { allopurinol } \\
\text { (all with } \\
\text { levodopa-induced } \\
\text { motor } \\
\text { fluctuations) }\end{array}$ & $\begin{array}{l}\text { Sum serial } \\
\text { UPDRS -III }{ }^{\ddagger} \\
\text { scores following a } \\
\text { levodopa dose } \\
(4 \mathrm{~h}) \text { and } \\
\text { including two } \\
\text { further doses } \\
(11 \mathrm{~h})\end{array}$ & $\begin{array}{l}\text { De-blinding at } \\
3 \text { months (repeat } \\
\text { biopsy in all at } \\
3 \text { months }\end{array}$ & $\begin{array}{l}\text { All triple therapy patients had } \\
\text { improved scores (excluding two } \\
\text { eradication failures), whereas, } \\
\text { in allopurinol group, there was } \\
\text { "lack of any significant change or } \\
\text { even a worsening". }\end{array}$ \\
\hline
\end{tabular}

* Interim analysis when recruitment stopped because of marked deterioration with failed eradication. At this stage, 31 participants had been randomised, including one drop-out with no data after blinded treatment, and 20 had reached de-blinding. ${ }^{* *}$ Final analysis includes all 30 with post-treatment assessment and follow-up to 3 years after blinded-active treatment or to 2 years after open-active (following blinded-placebo). ${ }^{+}$Isotope-labelled urea breath test. ${ }^{+\dagger}$ Proton pump inhibitor plus two antimicrobials. ${ }^{\#}$ Standard deviation. ${ }^{\mathbb{I}}$ Sample size calculation. $\ddagger$ Unified Parkinson's Disease Rating Scale Part III-motor section. 
Table 2. Non-randomised trials of effect Helicobacter eradication on severity of, and hypokinesia in, idiopathic parkinsonism.

\begin{tabular}{|c|c|c|c|c|c|c|}
\hline Study & $\begin{array}{c}\text { Ascertainment of } \\
\text { Helicobacter } \\
\text { Positivity }\end{array}$ & Interventions & $\begin{array}{c}\text { Number } \\
\text { Helicobacter-Positive } \\
\text { (Levodopa-Status) }\end{array}$ & $\begin{array}{c}\text { Primary Relevant } \\
\text { Outcome } \\
\text { Measures }\end{array}$ & $\begin{array}{l}\text { Duration Follow-Up } \\
\text { (Confirmation } \\
\text { Eradication) }\end{array}$ & Findings \\
\hline $\begin{array}{l}\text { Pierantozzi et al. } \\
\quad(2001) \text { [48] }\end{array}$ & $\begin{array}{c}\text { Anti-urease-IgG } \\
\text { serology (ELISA) }\end{array}$ & $\begin{array}{l}\text { 1-week placebo } \\
\text { followed by 1-week } \\
\text { fixed triple therapy }\end{array}$ & $\begin{array}{c}6 \\
\text { (all with } \\
\text { levodopa-associated } \\
\text { wearing-off } \\
\text { phenomenon) }\end{array}$ & UPDRS-III & $\begin{array}{l}2 \text { weeks after each } \\
\text { intervention (none) }\end{array}$ & $\begin{array}{c}\text { UPDRS score lower after triple } \\
\text { therapy than after placebo at } 2 \mathrm{~h} \\
\text { after levodopa test-dose but } \\
\text { not } 1 \mathrm{~h} .\end{array}$ \\
\hline $\begin{array}{c}\text { Lee et al. (2008) } \\
\text { [49] }\end{array}$ & UBT & $\begin{array}{c}\text { 1-week fixed triple } \\
\text { therapy }\end{array}$ & $\begin{array}{c}35 \\
\text { (all with } \\
\text { levodopa-induced } \\
\text { motor fluctuations) }\end{array}$ & UPDRS-III & $\begin{array}{c}3 \text { months (UBT at } \\
9 \text { weeks) }\end{array}$ & $\begin{array}{c}\text { Numerical, but not statistically } \\
\text { significant, reduction in UPDRS } \\
\text { after eradication (excluding one } \\
\text { eradication failure). }\end{array}$ \\
\hline $\begin{array}{c}\text { Hashim et al. (2014) } \\
\text { [50] }\end{array}$ & UBT & $\begin{array}{l}\text { 1-week fixed triple } \\
\text { therapy }\end{array}$ & $\begin{array}{l}21^{*} \\
\text { (levodopa therapy for } \\
\geq 1 \text { month) }\end{array}$ & $\begin{array}{l}\text { UPDRS-III } \\
\text { PDQ-39 }^{+}\end{array}$ & $\begin{array}{c}12 \text { weeks (UBT at } \\
12 \text { weeks) }\end{array}$ & $\begin{array}{l}\text { UPDRS and PDQ scores } \\
\text { (including mobility) improved } \\
\text { significantly (by } 13 \text { and } 19 \text { points, } \\
\text { respectively) after eradication. }\end{array}$ \\
\hline $\begin{array}{c}\text { Liu et al. (2017) } \\
\text { [51] }\end{array}$ & UBT & $\begin{array}{c}\text { 2-week fixed triple } \\
\text { therapy }\end{array}$ & $\begin{array}{c}24 \\
\text { (half untreated) } \\
\text { (levodopa used but } \\
\text { not inclusion } \\
\text { criterion) }\end{array}$ & UPDRS-III & 1 year (UBT at 1 year) & $\begin{array}{l}\text { Within triple therapy patients, } \\
\text { and by comparison with } \\
\text { untreated, improvement in } \\
\text { UPDRS score, mainly } \\
\text { brady/hypokinesia subscores } \\
\text { (excluding two } \\
\text { eradication failures). }\end{array}$ \\
\hline
\end{tabular}

* After excluding six drop-outs. ${ }^{+}$Parkinson's Disease Questionnaire (disability) 
Table 3. Cross-sectional observational studies of relationship of Helicobacter-status to motor severity and hypokinesia within idiopathic parkinsonism.

\begin{tabular}{|c|c|c|c|c|}
\hline Study & $\begin{array}{c}\text { Ascertainment of } \\
\text { Helicobacter Positivity }\end{array}$ & $\begin{array}{l}\text { Number of IP * Participant(s) } \\
\text { (Levodopa-Status) }\end{array}$ & $\begin{array}{c}\text { Primary Relevant Outcome } \\
\text { Measures }\end{array}$ & Findings \\
\hline Weller et al. (2005) [52] & $\begin{array}{l}\text { Serum immunoblot } \\
\text { antibody profile }\end{array}$ & $\begin{array}{l}124 \text { with immunoblot profile } \\
\text { ( } 81 \% \text { on levodopa, evenly } \\
\text { spaced to minimise fluctuations) }\end{array}$ & $\begin{array}{l}\text { Stride length and its } \\
\text { deterioration over } 4 \text { years } \\
\text { Webster Rating } \\
\text { Scale }\end{array}$ & $\begin{array}{l}\text { Gradients of clinically relevant size between } \\
\text { "discriminant index for IP-status" (based on } \\
\text { immunoblot) and shorter stride length and } \\
\text { more deterioration over } 4 \text { years. Gradient } \\
\text { between index and Webster rating. }\end{array}$ \\
\hline $\begin{array}{l}\text { Lee et al. } \\
(2008)[49]\end{array}$ & UBT & $\begin{array}{c}30 \text { Helicobacter-negative, } 35 \\
\text { positive (all on levodopa) }\end{array}$ & UPDRS-III $^{+}$ & No difference in UPDRS. \\
\hline Hashim et al. (2014) [50] & UBT & $\begin{array}{l}53 \text { Helicobacter-negative, } \\
21 \text { positive (all on levodopa for } \\
\geq 1 \text { month) }\end{array}$ & $\begin{array}{l}\text { UPDRS-II and -III } \\
\text { PDQ-39 }^{+}\end{array}$ & $\begin{array}{l}\text { Helicobacter-positives had worse UPDRS } \\
\text { and PDQ scores. }\end{array}$ \\
\hline Narozanska et al. (2014) [53] & Stool antigen & $\begin{array}{c}48 \text { Helicobacter-negative, } \\
25 \text { positive } \\
\text { (all with levodopa-induced } \\
\text { motor fluctuations) }\end{array}$ & UPDRS-III $^{+}$ & $\begin{array}{l}\text { No difference between Helicobacter-positives } \\
\text { and -negatives in UPDRS. }\end{array}$ \\
\hline $\begin{array}{l}\text { Bu et al. } \\
(2005)[54]\end{array}$ & $\begin{array}{l}\text { Anti-urease-IgG serology } \\
\text { (ELISA) }\end{array}$ & $\begin{array}{l}131 \text { with antibody-status } \\
\text { against six pathogens (including } \\
\text { H. pylori), compared with } 141 \\
\text { without IP (unspecified number } \\
\text { on levodopa) }\end{array}$ & Schwab and England Stage ${ }^{\dagger}$ & $\begin{array}{l}\text { Infection burden, based on number } \\
\text { seropositivities for six pathogens, associated } \\
\text { with having IP and its Schwab and } \\
\text { England Stage. }\end{array}$ \\
\hline Tan et al. (2015) [55] & UBT & $\begin{array}{c}69 \text { Helicobacter-negative, } \\
33 \text { positive (unspecified number } \\
\text { on levodopa) }\end{array}$ & $\begin{array}{c}\text { UPDRS-III } \\
\text { Timed walking test } \\
\text { Purdue Pegboard test }\end{array}$ & $\begin{array}{l}\text { Helicobacter-positive had worse UPDRS, longer } \\
\text { timed waking test and inserted fewer pegs in } \\
\text { allotted time. }\end{array}$ \\
\hline Esmael et al. (2016) [56] & $\begin{array}{l}\text { Anti-urease-IgG serology } \\
\text { (ELISA) }\end{array}$ & $\begin{array}{c}27 \text { Helicobacter-negative, } \\
\text { 23-positive } \\
\text { (all with levodopa-induced } \\
\text { motor fluctuations) }\end{array}$ & 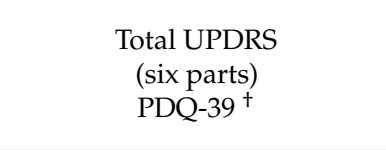 & $\begin{array}{l}\text { UPDRS and PDQ worse in } \\
\text { Helicobacter-positive. }\end{array}$ \\
\hline Roshan et al. (2018) [57] & $\begin{array}{l}\text { Anti-urease-IgG serology } \\
\text { (ELISA) }\end{array}$ & $\begin{array}{c}\text { 66 Helicobacter-negative, } \\
\text { 33-positive (no information on } \\
\text { levodopa receipt) }\end{array}$ & UPDRS-II \& -III ${ }^{\dagger}$ & $\begin{array}{l}\text { No difference between Helicobacter-positive } \\
\text { and -negative in UPDRS. }\end{array}$ \\
\hline
\end{tabular}

* idiopathic parkinsonism. ${ }^{\dagger}$ Hoehn \& Yahr Stage also performed but no difference found in Stage according to Helicobacter-status. 
Table 4. Cross-sectional observational studies of relationship of Helicobacter-status to other outcomes in idiopathic parkinsonism.

\begin{tabular}{|c|c|c|c|c|}
\hline Study & $\begin{array}{c}\text { Ascertainment of } \\
\text { Helicobacter-Positivity }\end{array}$ & $\begin{array}{c}\text { Number Participants } \\
\text { (Levodopa-Status) }\end{array}$ & $\begin{array}{l}\text { Primary Relevant } \\
\text { Outcome Measure }\end{array}$ & Findings \\
\hline Dobbs et al. (2005) [58] & $\begin{array}{l}\text { Serum immunoblot } \\
\text { antibody profile }\end{array}$ & $\begin{array}{l}124 \text { with IP and } 194 \text { without IP } \\
\text { ( } 81 \% \text { on levodopa, evenly } \\
\text { spaced to minimise fluctuations) }\end{array}$ & Body mass index & $\begin{array}{l}\text { Odds of being underweight tripled in presence } \\
\text { of anti-VacA }{ }^{\dagger} \text { antibodies, irrespective of } \\
\text { IP-status. }\end{array}$ \\
\hline Suwarnalata et al. (2016) [59] & $\begin{array}{c}\text { Serology (ELISA), } \\
\text { anti-CagA, }{ }^{++} \text {anti-H. pylori } \\
\text { whole cell }\end{array}$ & $\begin{array}{l}60 \text { with IP, of which } 30 \\
\text { seropositive (unspecified } \\
\text { number on levodopa) }\end{array}$ & Autoantibody screen & $\begin{array}{l}13 \text { autoantibodies "against proteins essential } \\
\text { for normal neurological functions" } \\
\text { discriminated Helicobacter-positive } \\
\text { from -negative. }\end{array}$ \\
\hline Fasano et al. (2013) [60] & UBT & $\begin{array}{c}33 \text { with IP of which } 11 \\
\text { UBT-positive and } 18 \text { hydrogen } \\
\text { breath test positive for SIBO } \\
\text { (all with levodopa-induced } \\
\text { motor fluctuations) }\end{array}$ & $\begin{array}{l}\text { Levodopa-induced } \\
\text { motor complications }\end{array}$ & $\begin{array}{l}\text { Unpredictable fluctuations were significantly } \\
\text { more with SIBO plus Helicobacter-positivity, } \\
\text { and tended to be more with SIBO alone, than } \\
\text { in absence of both. }\end{array}$ \\
\hline Rahne et al. (2013) [61] & UBT & $\begin{array}{l}40 \text { with IP of which } 20 \\
\text { UBT-positive (all } \\
\text { taking levodopa) }\end{array}$ & $\begin{array}{l}\text { Levodopa-induced } \\
\text { motor complications }\end{array}$ & Helicobacter-positives had worse UPDRS-IV. \\
\hline
\end{tabular}

${ }^{\dagger}$ anti-vacuolating toxin. ${ }^{+\dagger}$ anti-cytotoxin-associated gene product. ${ }^{\#}$ SIBO $=$ small intestinal bacterial overgrowth 
Table 5. Observational studies of comparative frequency of associated Helicobacter and idiopathic parkinsonism and its age relationship.

\begin{tabular}{|c|c|c|c|c|c|}
\hline Study & $\begin{array}{l}\text { Ascertainment of } \\
\text { Helicobacter } \\
\text { Positivity }\end{array}$ & Country & $\begin{array}{c}\text { Number } \\
\text { Participants or } \\
\text { Samples }\end{array}$ & Participant/Sample Source & Findings \\
\hline Dobbs et al. (2000) [62] & $\begin{array}{l}\text { Anti-urease-IgG } \\
\text { serology (ELISA) }\end{array}$ & UK & $\begin{array}{l}105 \text { with IP, } \\
210 \text { controls }\end{array}$ & $\begin{array}{l}\text { Call for volunteers with and } \\
\text { without IP followed by screening } \\
\text { for inclusion/exclusion criteria. }\end{array}$ & $\begin{array}{l}\text { Controls showed birth cohort } \\
\text { effect. Having IP obliterated this. } \\
\text { Higher frequency of } \\
\text { Helicobacter-positive, up to } \\
72.5 \text { years, in IP than in controls. }\end{array}$ \\
\hline Weller et al. (2005) [52] & $\begin{array}{c}\text { Immunoblot } \\
\text { serology } \\
\text { Anti-urease-IgG } \\
\text { serology (ELISA) }\end{array}$ & UK & $\begin{array}{l}124 \text { with IP, } \\
196 \text { without }\end{array}$ & $\begin{array}{l}\text { Consecutive IP patients attending } \\
\text { clinic and consecutive responders } \\
\text { to call for healthy volunteers } \\
\text { from same locality. Similar } \\
\text { inclusion/exclusion criteria } \\
\text { applied to both, except diagnosed } \\
\text { IP an exclusion in controls. }\end{array}$ & $\begin{array}{l}\text { Controls showed a birth cohort } \\
\text { effect for odds of having VacA } \\
\text { antibody. Having IP obliterated } \\
\text { this. Predicted probability of IP } \\
\text { greatest with CagA-positivity, } \\
\text { VacA-negativity and urease-B } \\
\text { negativity. Discrimination not } \\
\text { complemented by ELISA. }\end{array}$ \\
\hline Nielsen et al. (2012) [63] & $\begin{array}{c}\text { Helicobacter } \\
\text { eradication course }\end{array}$ & Denmark & $\begin{array}{l}4484 \text { with IP, } \\
22416 \text { controls }\end{array}$ & $\begin{array}{l}\text { Danish National Patient Register } \\
\text { for diagnosis IP, dated to first } \\
\text { prescription IP drug. National } \\
\text { Prescription Registry. Index date } \\
\text { for IP diagnosis between } 2001 \text { and } \\
\text { 2008, eradication date from } 1995 . \\
\text { Danish Civil Registration System } \\
\text { source of } 5 \text { matched controls per } \\
\text { IP patient. }\end{array}$ & $\begin{array}{l}\text { Frequency of historical } \\
\text { Helicobacter eradication increased } \\
\text { in IP, even when only eradications } \\
\geq 5 \text { years prior to IP assessed. }\end{array}$ \\
\hline Blaecher et al. (2013) [64] & $\begin{array}{l}\text { For H. pylori: } \\
\text { culture and PCR in } \\
\text { culture negative } \\
\text { For H. suis: PCR. }\end{array}$ & UK & $\begin{array}{l}60 \text { DNA extracts from } \\
\text { people with IP, } \\
\text { 256 DNA extracts } \\
\text { from people attending } \\
\text { endoscopy } \\
\text { departments }\end{array}$ & $\begin{array}{l}\text { Serial archived DNA extracts } \\
\text { from Helicobacter Reference } \\
\text { Laboratory, Public Health } \\
\text { England, with selection for } \\
\text { adequate documentation and } \\
\text { whether from IP clinic or not. }\end{array}$ & $\begin{array}{c}\text { Relative risk of } H \text {. suis compared } \\
\text { with } H \text {. pylori } 10 \text { times greater in } \\
\text { IP than in controls. }\end{array}$ \\
\hline
\end{tabular}


Table 5. Cont.

\begin{tabular}{|c|c|c|c|c|c|}
\hline Study & $\begin{array}{l}\text { Ascertainment of } \\
\text { Helicobacter } \\
\text { Positivity }\end{array}$ & Country & $\begin{array}{l}\text { Number } \\
\text { Participants or } \\
\text { Samples }\end{array}$ & Participant/Sample Source & Findings \\
\hline Fasano et al. (2013) [60] & UBT & Italy & $\begin{array}{l}33 \text { with IP, } \\
30 \text { spouses of IP } \\
\text { probands }\end{array}$ & $\begin{array}{l}\text { Consecutive IP patients attending } \\
\text { a hospital and their spouses. }\end{array}$ & $\begin{array}{l}\text { Similar frequency of Helicobacter } \\
\text { positivity in IP } \\
\text { and spouses. }\end{array}$ \\
\hline Bu et al. (2005) [54] & $\begin{array}{c}\text { Anti-urease-IgG } \\
\text { serology (ELISA) }\end{array}$ & China & $\begin{array}{c}131 \mathrm{IP} \\
141 \text { controls }\end{array}$ & $\begin{array}{l}\text { Consecutive IP patients attending } \\
\text { a hospital. Controls randomly } \\
\text { recruited from hospital's clinics } \\
\text { over same period. }\end{array}$ & $\begin{array}{l}\text { Higher frequency of Helicobacter } \\
\text { positivity in IP. }\end{array}$ \\
\hline Esmael et al. (2016) [56] & $\begin{array}{l}\text { Anti-urease-IgG } \\
\text { serology (ELISA) }\end{array}$ & Egypt & $\begin{array}{l}50 \text { with IP, } \\
20 \text { controls }\end{array}$ & $\begin{array}{l}\text { IP patients from neurology } \\
\text { outpatients. Age and gender } \\
\text { matched controls with no } \\
\text { diagnosed neurological disease. }\end{array}$ & $\begin{array}{l}\text { Higher frequency of Helicobacter } \\
\text { positivity in IP. }\end{array}$ \\
\hline Huang et al. (2018) [65] & $\begin{array}{l}\text { Endoscopic-biopsy, } \\
\text { with UBT where } \\
\text { endoscopy not } \\
\text { tolerated }\end{array}$ & Taiwan & $\begin{array}{c}9186 \\
\text { Helicobacter-positive } \\
\text { (reduced to } 9105 \text { after } \\
\text { matching), } \\
9105 \\
\text { Helicobacter-negative }\end{array}$ & $\begin{array}{l}\text { “2000 Longitudinal Health } \\
\text { Insurance Database". Propensity } \\
\text { score matching based on age, sex, } \\
\text { income, urbanization, } \\
\text { comorbidities, medication). Index } \\
\text { date } 2000 \text { to } 2011 \text { inclusive. } \\
\text { Follow-up until } \\
\text { IP diagnosis, death or latest } 2012 .\end{array}$ & $\begin{array}{c}\text { Increased estimated incidence IP } \\
\text { in Helicobacter-positive } \geq 60 \text { years, } \\
\text { irrespective of eradication } \\
\text { therapy. }\end{array}$ \\
\hline Roshan et al. (2018) [57] & $\begin{array}{l}\text { Anti-urease-IgG } \\
\text { serology (ELISA) }\end{array}$ & Iran & $\begin{array}{c}99 \text { with IP, } \\
297 \text { controls } \\
\text { Exclusion if history of } \\
\text { Helicobacter } \\
\text { eradication }\end{array}$ & $\begin{array}{l}\text { Consecutive IP patients in } \\
\text { neurology clinic. "Amirkola } \\
\text { Health and Ageing Project": } \\
\text { three controls, with no history of } \\
\text { IP drugs, matched to each IP } \\
\text { proband for age and gender. }\end{array}$ & $\begin{array}{l}\text { Lower frequency of Helicobacter } \\
\text { positivity in IP. }\end{array}$ \\
\hline
\end{tabular}




\subsection{Study Findings}

\subsubsection{Trials of Helicobacter Eradication in IP}

Randomised Controlled Trials of Effect on IP Severity or Facets

In the first [46] of the two RCTs summarised in Table 1, the protocol analysis of within-subject time trends in 6-weekly observations showed an improvement (by, on average, $7.3 \mathrm{~cm}$ ) in mean stride length over the year after blinded active Helicobacter eradication therapy, compared with after placebo. The size of this effect was unaffected by whether participants were receiving stable long $t \frac{1}{2}$ anti-parkinsonian medication or were treatment-naïve. There was a marked worsening in stride length $(29 \mathrm{~cm})$ in the four participants with failed eradication, compared with the successful participants (even though persistence could be detected only at molecular level in two). This was reflected in changes in the global visual analogue ratings of stance and gait videos. The improvement in hypokinesia occurred despite an increase in rigidity post-eradication. The differential effect on hypokinesia and rigidity was replicated following open active, post-placebo. Improvements in hypokinesia plateaued from one year after active until the 3-year study endpoint. Rigidity plateaued in year 2 but showed a small deterioration in year 3 .

In the second RCT [47], 3 months after the allocated treatment, all those receiving eradication therapy had an improved within-day grand total for multiple repeats of the UPDRS motor score, except for two with eradication failure. A lack of change or worsening was seen in the allopurinol comparator arm. "On-time" (defined there as the total duration with a 20\% reduction in total UPDRS motor score from the day's baseline) reflected the above findings.

Non-Randomised Trials of Effect on IP Severity or Facets

Of the four open trials (Table 2), one [50] found large improvements in the total UPDRS motor score and in PDQ-39, including its mobility domain, at 12 weeks post-eradication. Another [51] found an improvement, over the baseline, at one year following Helicobacter eradication, in both the total UPDRS motor score and its subscores relating to upper and lower limb brady/hypokinesia (after excluding two eradication failures). This improvement was over and above any longitudinal changes in a comparator IP group with untreated Helicobacter infections.

Of the two trials with motor fluctuations as an inclusion criterion, in one [48], the UPDRS motor score, $2 \mathrm{~h}$ after levodopa, was better at 2 weeks after active eradication than it had been after the preceding placebo course. In the other [49], there was a numerical, but not statistically significant, improvement in the total UPDRS motor score 3 months after intervention (after excluding one eradication failure).

\subsubsection{Biological Gradients of Helicobacter Serology on Disease Burden in IP}

The first study [52], in Table 3, is an observational study with dramatic effects. It describes the biological gradients, of clinically relevant size, between disease burden and a discriminant index for IP, based on the Western blot pattern of IgG antibodies against electrophoretically separated H. pylori antigens. The higher the index, the shorter the stride length and the greater global IP severity on the Webster scale. Moreover, the higher the index, the greater the deterioration in stride length over 4 years.

\subsubsection{Cross-Sectional Associations of Helicobacter-Status in IP}

With Global and Facet Assessments

Of the other studies in Table 3, Helicobacter positivity was associated with significantly worse total UPDRS motor scores $[50,55,56]$, PDQ-39 scores [50,56] and bradykinesia in the timed walking and pegboard tests [55]. All of these studies, apart from one [56], assessed current Helicobacter-status. 
In contrast, two studies [53,57] showed no difference in total UPDRS motor scores between the Helicobacter-positive and -negative (in stool antigen and serology, respectively). One study [54] conflated Helicobacter seropositivity with a wider infection burden.

Functional staging (Hoehn and Yahr) was used as an outcome in several studies but was insensitive to Helicobacter-status across the board.

\section{With Other Outcomes}

Of the four cross-section observational studies in Table 4, the outcomes were body mass index [58], serum autoantibodies [59] and motor complications of levodopa therapy [60,61]. The latter are discussed below (Section 3.3.4). Regarding body mass index, although the odds of being underweight nearly tripled in the presence of seropositivity for the Helicobacter pathogenicity marker, vacuolating toxin (VacA), this was independent of IP-status [58]. The presence of "elevated autoantibodies against proteins essential for normal neurological functions" was greater in H. pylori-seropositive IP probands than in the seronegative IP probands [59].

\subsubsection{Effect of Helicobacter Eradication or Status on Clinical Pharmacology of Levodopa}

\section{Pharmacokinetics}

Helicobacter eradication has been associated with an increased area under the 4-h levodopa concentration/time profile (related to a single morning dose) and the 11-h profile (which included subsequent levodopa dosing), both in a pilot study [48] and a subsequent RCT [47]. Ascertainment of H. pylori-status was by serology and endoscopic biopsy, respectively. However, in a cross-sectional study, current $H$. pylori-status did not significantly influence either the area under the 4-h concentration/time curve for levodopa or 3-O-methyldopa (its long $\mathrm{t} \frac{1}{2}$ metabolite), with or without computed extrapolation beyond $4 \mathrm{~h}$ [53].

\section{Pharmacodynamics}

All three options for motor complications of levodopa therapy, decreased, increased and unaffected, have been reported as being associated with Helicobacter, mostly decreased. Following eradication, a shortened onset time of the levodopa effect, a prolonged switched-on-time and a tempering of end-of-dose wearing-off have been reported $[47,49,50]$. In cross-sectional studies, longer onset accompanied by shorter on-time distinguished the UBT-positive [49] and the seropositive [56] from the negative. On/off fluctuations were more apparent when UBT-positivity co-existed with small intestinal bacterial overgrowth (SIBO) [60]. In contradiction, another cross-sectional comparison showed less wearing-off with UBT-positivity in IP [61]. Others found no difference in dyskinesias or motor fluctuations between seropositive and seronegative groups [57].

\subsubsection{Longitudinal Follow-Up of Untreated Helicobacter Infection in IP}

One study [51] had a cohort of 12 UBT-positive IP patients who chose not to receive Helicobacter eradication. On follow-up to one year, a differential effect of Helicobacter infection on UPDRS motor subscores was seen: rigidity became considerably better numerically (by two on a five-point scale), whilst upper and lower limb brady/hypokinesia and rest tremor became worse numerically. However, the placebo arm in a year-long blinded phase of an RCT of H. pylori eradication in IP [46] showed no change in either objectively measured brady/hypokinesia or rigidity, or in visual analogue ratings of hand tremor (whilst seated or during stance and walking).

In an inception cohort [65], with the ascertainment of Helicobacter infection by biopsy or UBT, the increased risk of IP diagnosis 4 years on was irrespective of eradication therapy. 


\subsubsection{Inter-Relationship between Helicobacter and IP}

How Common Is IP with or after Helicobacter Infection?

The increase in IP diagnosis with or after Helicobacter infection has been demonstrated in two studies [63,65] (Table 5). Interrogating the nationwide Danish registers showed that prior (5 years or more) prescription of Helicobacter eradication drugs was associated with a $45 \%$ increase in the diagnosis of IP [63]. The use of Taiwan's National Health Insurance Register, where Helicobacter infection was primarily diagnosed by endoscopic mucosal biopsy, showed a 129\% higher risk of IP associated with Helicobacter infection [65].

\section{How Common Is Helicobacter in IP?}

Of three cross-sectional comparisons of the frequency of testing seropositive for Helicobacter in people with and without IP (Table 5), two found a significant positive association [51,53] and one a negative association [54]. The lower frequency of seropositivity in IP in the latter may, in part, be attributable to excluding those with a history of Helicobacter eradication therapy. Another comparison found no difference in the frequency of UBT positivity, but controls were the spouses of the IP probands [60]. Non-H. pylori Helicobacter infection appears to be more common in IP: the relative frequency of $H$. suis (detected by PCR on gastric biopsies) to H. pylori was 10-times greater in IP patients than in routine gastroenterology patients undergoing endoscopic biopsy [64].

Effect of Age on Relationship between Helicobacter and IP

In Table 5, one study [62] shows that seropositivity for anti-urease-IgG antibody was greater in IP than in controls, until the age of 72 years. This was in contrast to the expected birth cohort effect (increasing frequency with age) seen in controls of similar social class representation. The predicted probability of being labelled as having IP was greatest with a particular profile of $H$. pylori virulence marker antibodies [52]. With this profile, the odds for parkinsonism increased from around aged 70 years, being fivefold by the age of 80 years.

\subsection{Risk of Bias}

Table 6 gives the available information on the risk of bias in the two double-blind RCTs of Helicobacter eradication [45-47]. Both studies appear of low risk generally. However, in one [47], there was a lack of clarity in the allocation concealment of treatments and in reporting whether the analysis was of proven eradication. There was also a risk of detection bias due to the repeated subjective assessments, with the potential for a carry-over effect.

Table 6. Risk of bias assessment of randomised placebo-controlled trials.

\begin{tabular}{|c|c|c|c|c|c|c|}
\hline \multirow[b]{2}{*}{ Citation } & \multicolumn{2}{|c|}{ Selection Bias } & \multirow{2}{*}{$\begin{array}{l}\begin{array}{c}\text { Performance } \\
\text { Bias }\end{array} \\
\text { Blinding of } \\
\text { Participants } \\
\text { \& Personnel }\end{array}$} & \multirow{2}{*}{$\begin{array}{l}\text { Detection } \\
\text { Bias } \\
\text { Blinding of } \\
\text { Outcome } \\
\text { Assessment }\end{array}$} & \multirow{2}{*}{$\begin{array}{c}\text { Attrition } \\
\text { Bias } \\
\text { Incomplete } \\
\text { Outcome } \\
\text { Data }\end{array}$} & \multirow{2}{*}{$\begin{array}{c}\begin{array}{c}\text { Reporting } \\
\text { Bias }\end{array} \\
\text { Selective } \\
\text { Reporting }\end{array}$} \\
\hline & $\begin{array}{l}\text { Random } \\
\text { Sequence } \\
\text { Generation }\end{array}$ & $\begin{array}{l}\text { Allocation } \\
\text { Concealment }\end{array}$ & & & & \\
\hline$[45,46]$ & low & low & low & low & low & low \\
\hline [47] & low & unclear * & low & moderate $\dagger$ & low & unclear \# \\
\hline
\end{tabular}




\section{Discussion}

Our primary interest is in whether Helicobacter infection has an aetiopathogenic role in the evolution of IP and, if so, what processes are involved. A foundation is provided by understanding the inter-relationship of Helicobacter and IP and the effect of Helicobacter eradication, compared with no attempt at eradication or failed eradication. However, in a syndrome with a long prodrome and very variable manifestations between probands, where facets do not progress in parallel, unification under a single driver is unlikely [66]. Halting one disease progression pathway by eradicating Helicobacter may allow escape down subordinate ones. Moreover, there may be effect modifiers from the onset (e.g., human genetics) and en route (smoking).

There are three systematic reviews and/or meta-analyses of Helicobacter in IP. The 2011 review of six studies up to 2006 states the precondition that "potential benefits of Helicobacter eradication need to be balanced against the costs of screening and treatment" [67]. The worsening of hypokinesia with failed eradication was dismissed as an adverse treatment effect rather than being put together with improved hypokinesia with successful eradication. The 2017 meta-analysis of eight studies up to 2015 demonstrated a positive association between IP and Helicobacter [68]. The 2018 meta-analysis of 10 studies up to 2017 confirmed this association and found a global severity score for IP to be higher in the infected (seven studies), reduced after Helicobacter eradication (five) [69]. We review 20 studies up to 2019 , addressing the following questions.

\subsection{Three Questions Addressed by Systematic Review}

\subsubsection{Effect of Helicobacter Eradication Therapy in IP}

This systematic review complements the 2018 meta-analysis [69] in upgrading the level of OCEBM evidence to 1 for "Does this intervention (Helicobacter eradication) help?" The upgrade takes on board Level-2 evidence from RCTs [45-47] and an observational study with dramatic effect [52]. Three of the four non-randomised trials [48,50,51] (one of which had a dramatic effect [50]) provide supportive Level-3 evidence. In the other, the improvement seen did not reach statistical significance [49].

The "help" was manifested as a lessening of global motor severity and/or a reduction in brady/hypokinesia. A benefit over a short period could be a non-specific effect of eliminating infection [47,48], but one RCT had a follow-up for three years [46] and an open eradication study for one year [51]. Helicobacter infection is linked to brady/hypokinesia cross-sectionally [52,55]. Hypokinesia lessens on the planned experiment of eradication [46,51] and increases markedly with the natural experiment of failed eradication [45,46]. With failure, the bolus release of the antigen from the killed bacteria might aggravate the immune response to the ongoing infection.

The effect of Helicobacter eradication may be disease modification: a differential effect was seen in IP probands (mean age 60 years) on IP facets, with less hypokinesia and more rigidity [45,46]. Reciprocal trends of worsening brady/hypokinesia and lessening rigidity subscores were seen in IP probands with untreated Helicobacter [51]. A pilot study [58] addressed whether the same antimicrobial intervention but for another indication would have the same outcome. Anti-Helicobacter therapy was given to IP probands who had antral-predominant gastritis but were biopsy-negative for $H$. pylori (rapid-urease test, histology, culture and molecular methods). No disease-modifying effect was seen.

The subsequent surveillance of all antimicrobial prescriptions in IP patients [70], with stable antiparkinsonian medication, confirmed the specificity of improved hypokinesia and bradykinesia (15 cm/year in mean stride length and $0.2 \mathrm{~m} / \mathrm{s} /$ year in free walking speed) to the indication of Helicobacter infection. The effect on rigidity was not indication-specific: there was a cumulative increase in objectively measured rigidity following successive antimicrobial exposures for other indications (by $18 \%$ after a second course and a further $17 \%$ after a third). Helicobacter pylori infection might keep a rigidity-provoking source of inflammation at bay and/or eradication therapy predispose to rigidity-provoking microbiota in the small intestine and/or colon. Indeed, in IP, there is an inverse relationship between the presence of $H$. pylori and that of SIBO [71]. Moreover, an extensive 
dataset shows the plateauing of the year-on-year increase in objectively measured rigidity after introducing maintenance laxative [72], giving further indicative evidence for a rigidity-provoking intestinal dysbiosis.

\subsubsection{Consequences of Not Eradicating Helicobacter in IP}

There is prima facie Level-1 OCEBM evidence on "What will happen if we do not add a therapy (eradication)?" from the current systematic review of the (Level-2) inception cohort studies [51,65], complemented by the placebo-control arm of an RCT (Level-3) [45,46]. Seemingly, there would be no change. However, the one to four years' follow-up available is not sufficient to capture the evolution of a disease that develops over decades, with a median age at diagnosis between 60 and 69 years [73]. Since Helicobacter is a carcinogen, to leave it untreated (even after the endoscopic exclusion of neoplasm) for more than a year was considered inadvisable $[45,46]$. This, in retrospect, was a reasonable decision since nearly half were found to have pangastritis or corpus-predominant gastritis, rather than antral-predominant, and a third had atrophy or intestinal metaplasia.

In one inception cohort [65], usually with biopsy ascertainment of Helicobacter infection, receipt or not of eradication therapy (at mean age of 51 years) did not influence the increased risk of IP diagnosis 4 years on. Although not disease preventing, there was no evidence as to whether eradication was disease-modifying (4.1.1). In the other inception cohort [51] (mean age 63 years), with UBT ascertainment, the rigidity subscore was considerably lower one year on where Helicobacter was not eradicated, the change not reaching statistical significance (4.1.1). The placebo arm (mean age 63 years) in a year-long blinded-phase of an RCT of $H$. pylori eradication in IP showed no significant change in brady/hypokinesia or rigidity [46]. Recording of the sensitive markers of evolution prospectively is needed to resolve this question (e.g., higher plasma interleukin- 6 concentrations were associated with a greater risk of IP 4 years on [74]).

\subsubsection{Inter-Relationship between Helicobacter and IP}

Level-1 OCEBM evidence on "How common is the problem (association between Helicobacter and IP)?" is based on registry sample surveys, either total [63] or random, with matching (including by age and gender) of controls [65]. These embrace the concept that previous Helicobacter infection may be as, or more, important than current to IP aetiopathogenesis. The evidence is complemented, at Level-2, by the current and previous systematic reviews $[68,69]$. It is supported by non-registry surveys of IP patients, specified $[52,54,64]$ or not specified $[56,62]$ as consecutive, with indication that controls were matched to local circumstances $[52,54,64,65]$. Historical or contemporaneous Helicobacter is more commonly associated with IP than expected but with wide geographical variation.

Over and above different methods of ascertaining IP- and Helicobacter-status, the risk of the two being associated appeared considerably higher in Taiwan [65] than in Denmark [63]. This may relate to greater virulence conferred by East Asian-type cag pathogenicity island genes (manifest as gastric mucosal inflammatory cell infiltration; secretion of the pro-inflammatory cytokine, interleukin-8; and translocation of CagA into host cells) [75]. Even in Europe, a particular profile of antibodies against pathogenicity markers is predictive of the current disease burden and deterioration of IP over time [52]. As with gastric cancer, where a causal link to Helicobacter is well established, the birth cohort effect appears not to apply to IP patients: this was demonstrated with respect both to anti-urease ELISA antibody and immunoblot anti-VacA [52,62].

A 12-fold increase in all-cause mortality in IP has been associated with endoscopic biopsy positivity for an NHPH (H. suis) [76]. In the general population, H. pylori is specifically associated with gastric cancer deaths but not with all-cause mortality [77]. The magnitude of the H. suis effect warrants further investigation, more so in the light of the reported 10-fold greater relative frequency of $H$. suis to $H$. pylori in IP [64]. Frequency of H. suis was greatest in those who had received anti-H. pylori therapy: co-infecting H. suis may be filling the niche after H. pylori eradication. This would also fit with $H$. suis having different antimicrobial susceptibilities from $H$. pylori [78]. Human infection 
with NHPH is characteristically sparse and patchy, the load usually being insufficient to detect by UBT [64,76]. At present, there is one case report [58] on successful NHPH eradication in IP, with loss of antral gastritis and the associated corkscrew organisms. The patient went from wheelchair-bound and cachectic to maintaining independent mobility and weight increase during the 4-year follow-up on stable anti-parkinsonian medication. The reverse clinical picture was seen, following a third failed attempt at eradication, in an IP patient with H. pylori-like organisms associated with pangastritis.

\subsection{Meeting Criteria for a Cause-Effect Relationship}

When Koch (1884) formulated four criteria to establish a causative relationship between a microbe and a disease, he did not have the tools for intervention studies. Regarding (i), The bacteria must be present in every case of the disease, in no disease where $H$. pylori is causal is infection present in every case [79], but other Helicobacter species are not generally sought. Regarding (ii), The bacteria must be isolated from the host with the disease and grown in pure culture, isolating $H$. pylori from IP probands, and culturing it, is a positive attribute of the two RCTs in IP [45-47]. Regarding (iii), The specific disease must be reproduced when a pure culture of the bacteria is inoculated into a healthy susceptible host, IP is described only in humans, but chronic infection with Helicobacter might exacerbate or accelerate genetically modified animal models of hereditary parkinsonism. Regarding (iv), The bacteria must be recoverable from the experimentally infected host, Marshall $[4,5]$ infected himself with $H$. pylori, producing gastritis, and subsequently eradicated it, but the latency to clinical IP may be in decades and post-date prolonged infection.

Bradford Hill (1965) [80] added, "The clear dose-response curve admits of a simple explanation": that is causality. The discriminant index for IP, based on the anti-H. pylori immunoblot [52], provides an example of the quantification of pathogenicity in a dose-response relationship. Presuming that the index components are not surrogates for the pathophysiological drivers, the challenge is to understand the mechanisms.

\subsection{Limitations and Avoiding A Priori Assumptions}

\subsubsection{Limitations}

The nature of a systematic review is to define its limits. Given that the current consensus is that IP is gut-driven and gut manifestations precede neurological diagnosis by decades [66], and immune manifestations by at least years [74], study timeframes appear to be a limitation. However, we avoid too narrow a definition of IP: it was not coherent with the above to base inclusion on a predictor of brain pathology [81] and exclude pure clinical definition [82].

The quality of the data is another limitation. Objective measurements of IP facets were used only in one eradication and two cross-sectional studies $[45,46,52,55]$. (e.g., Mean stride length is sensitive to the detection of small differences in the treatment effect [83] and discriminates well for IP-status, when corrected for any relevant demographic/anthropometric characteristics [42].) Indeed, in pragmatic hypothesis testing, sensitive, specific, continuous, objective measures are economical in sample size $[45,46]$. They avoid the carry-over effect on within-observer repetition. In contrast, using total global scores denies the possibility of selective cause/effect relationships. Moreover, effects on component subscores sensitive to intervention can be drowned out by unresponsive ones.

Inclusion of participants with levodopa-induced motor fluctuations may have obscured the effects of intervention and confounded cross-sectional comparisons. Studying the anti-IP treatment-naïve is a difficult but important option, recruiting those receiving only stable long half-time medication the next best.

Since the risk of failed Helicobacter eradication is considerable, false-negative conclusions may be drawn from judging the outcomes of eradication studies without protocol analysis of proven eradication. 
Low infection load of H. pylori appears important in IP [66] and is the norm for NHPH infection in humans. Thus, the determination of Helicobacter-status by endoscopic biopsy with histology, culture and molecular microbiology is ideal for research into the aetiopathogenesis of IP.

\subsubsection{Avoiding A Priori Assumptions}

The assumption that any clinical improvement in IP from Helicobacter eradication is down to increased levodopa bioavailability has been a diversion from the basic hypothesis that Helicobacter is a driver in the aetiopathogenic process. The first RCT [45,46] addressed the driver hypothesis by excluding those on levodopa, but, unfortunately, most of the other cohort descriptions include levodopa usage.

We question whether Helicobacter infection does, indeed, influence levodopa pharmacokinetics. The levodopa concentration/time relationship is complex per se, including multiple peaks [53] and the inhibition of its own absorption by delaying gastric emptying [84]. Faster gastric emptying after Helicobacter eradication is documented both in dyspepsia alone [85] and in IP [58]. One group [47,48] provide evidence that eradication increases the area under the levodopa concentration/time curve in IP, but this is not backed up by a comparison of the infected and non-infected [53].

A second question is whether the improved performance can be ascribed to an effect of Helicobacter eradication on levodopa handling in the absence of conclusive evidence for altered kinetics. Elevation of baseline performance, consequent to eradicating Helicobacter [4.1.1], would be expected, in itself, to shorten the apparent levodopa onset time, prolong on-time and alleviate wearing-off. Moreover, it is a misconception that the increased area under the levodopa concentration/time curve equates to less severe motor fluctuations. On the contrary, increasing the effective levodopa dosage would be expected, down the line, to worsen existing fluctuations [86]. Time outside a therapeutic window of concentrations is likely to be the determinant of on/off fluctuations in performance and of dyskinesia. Pulsatile stimulation of dopaminergic receptors, consequent to faster absorption, may contribute to developing dyskinesia [87]. Inflammation alone may lower the threshold for dyskinesia and motor fluctuations. In a case report of treated NHPH infection, the onset of severe dyskinesia coincided with the return of UBT positivity, signalling recrudescence/reinfection [58]. Fluctuations are more severe where Helicobacter and SIBO coincide [60]: the gradual evolution of SIBO could be a determinant of delay in the onset of motor complications of levodopa. Wastage of levodopa, marked by the accumulation over time of its long $\mathrm{t} \frac{1}{2}$ metabolite 3-O-methylodopa, may contribute to "wearing-off" [88].

\subsection{Processes, Mechanisms and Explanations}

Associations of IP with human leukocyte antigen-DR isotype (HLA-DR) gene loci suggest classical autoimmunity [66]. Alternatively, there could be cross-reactivity through innate pattern recognition of the Helicobacter genus or of a broader microbial community. In IP, the benefit of eradicating H. pylori on hypokinesia is independent of infection load [46]. Its persistence at a low density appears just as detrimental as at high density. All eradication failures were anti-nuclear antibody (ANA) positive, and ANA-positivity reduced the beneficial effects of "successful" eradication. Others found that autoantibodies potentially detrimental to neuronal function are associated with $H$. pylori seropositivity in IP [59].

The predicted probability of being labelled parkinsonian was greatest with anti-CagA positivity and anti-VacA and urease-B negativity [52]. This antibody profile predicted global severity, and hypokinesia and its deterioration over 4 years, within IP. There is an established link between CagA and autoimmunity in thrombocytopenic purpura [89]. Anti-CagA cross-reacts with peptides on platelets: these antibodies decline following eradication when platelet counts improve. VacA has an important role in dampening immune responses and in induction of immune tolerance early in life [90]. It shifts T-cell responses towards regulatory rather than effector functions. Thus, the absence of VacA, as in the pathogenic profile for IP, might facilitate autoimmunity driven by another antigen. Antibodies against CagA remain positive for longer than those to $H$. pylori surface antigens, such as urease B. Relying 
solely on anti-urease B antibodies might misclassify a significant proportion of patients who once had the infection [91].

\subsection{Clinical and Research Implications}

The inter-relationship of Helicobacter and IP is well-established. Eradicating H. pylori in IP in later adult life is disease-modifying but not disease-preventing. Eradication in childhood or young adults might reduce the risk of IP. As well as causing regression of the hypokinesia and an overall improvement in motor severity, H. pylori eradication appears to unlock the next stage in the natural history of IP, the development of rigidity. Already there are clues as to how rigidity can be exacerbated [70] or ameliorated [72]. Amelioration by improving intestinal transit needs to be prophylactic rather than rescue.

As a clinical consequence, screening for H. pylori and its eradication should be part of the routine assessment of IP. The research consequence is a building block in piecing together the aetiopathogenesis of IP. Helicobacter pylori virulence markers give potential mechanistic clues. The pathological impact of Helicobacter eradication on the gastrointestinal microbiota needs exploring in terms of both nature and site. The inverse relationship between H. pylori and gastric NHPH should not be ignored.

There is interest in a role for Helicobacter in other neuropsychiatric diseases, but IP has proven to be a good starting point since the syndrome lends itself to objective quantification and hence the definition of a pre-presentation state [35,42].

Author Contributions: All authors significantly participated in the drafting or critical revision of the manuscript and provided approval of the final submitted version. R.M.T. as a PhD student under guidance from R.J.D., S.M.D., C.W. and A.C. (Principal Clinical Investigators) and D.T., was involved in design and coordination of narrative and systematic reviews, interpretation of data, first drafting of manuscript. A.D.A. contributed to reviewing the literature, and advising R.M.T., A.C. reviewed the statistical analyses. B.H.H. and I.B. provided gastroenterological expertise in interpretation of results. All authors have read and agreed to the published version of the manuscript.

Funding: Our grateful thanks go to the Psychiatry Research Trust, London, the Cecil Pilkington Charitable Trust, and the Cyril Corden Trust. Thanks also go to Gordon Roddick, Christopher Norris, Louise Barton, Richard and Diana Gloyn, Alex and Lyn Orr, Jamie and Julia Korner and Stella Weston for their generous donations through the Psychiatry Research Trust.

Conflicts of Interest: The authors declare that there is no conflict of interest.

\section{References}

1. Hooi, J.K.Y.; Lai, W.Y.; Ng, W.K.; Suen, M.M.Y.; Underwood, F.E.; Tanyingoh, D.; Malfertheiner, P.; Graham, D.Y.; Wong, V.W.S.; Wu, J.C.Y.; et al. Global Prevalence of Helicobacter pylori Infection: Systematic Review and Meta-Analysis. Gastroenterology 2017, 153, 420-429. [CrossRef] [PubMed]

2. Mishra, S.; Singh, V.; Rao, G.R.K.; Jain, A.K.; Dixit, V.K.; Gulati, A.K.; Nath, G. Detection of Helicobacter pylori in stool specimens: Comparative evaluation of nested PCR and antigen detection. J. Infect. Dev. Ctries. 2008, 2, 206-210. [PubMed]

3. Kao, C.Y.; Sheu, B.S.; Wu, J.J. Helicobacter pylori infection: An overview of bacterial virulence factors and pathogenesis. Biomed. J. 2016, 39, 14-23. [CrossRef]

4. Robin Warren, J.; Marshall, B. Unidentified Curved Bacilli on Gastric Epithelium in Active Chronic Gastritis. Lancet 1983, 321, 1273-1275. [CrossRef]

5. Marshall, B.J.; Warren, J.R. Unidentified Curved Bacilli in the Stomach of Patients With Gastritis and Peptic Ulceration. Lancet 1984, 323, 1311-1315. [CrossRef]

6. Lee, Y.-C.; Chiang, T.-H.; Chou, C.-K.; Tu, Y.-K.; Liao, W.-C.; Wu, M.-S.; Graham, D.Y. Association between Helicobacter pylori Eradication and Gastric Cancer Incidence: A Systematic Review and Meta-analysis. Gastroenterology 2016, 150, 1113-1124. [CrossRef]

7. Zullo, A.; Hassan, C.; Ridola, L.; Repici, A.; Manta, R.; Andriani, A. Gastric MALT lymphoma: Old and new insights. Ann. Gastroenterol. 2014, 27, 27-33.

8. Zheng, Y.; Liu, M.; Shu, H.; Chen, Z.; Liu, G.; Zhang, Y. Relationship between oral problems and Helicobacter pylori infection. Arch. Oral Biol. 2014, 59, 938-943. [CrossRef] 
9. Ogaya, Y.; Nomura, R.; Nakano, K.; Watanabe, Y. Detection of Helicobacter pylori DNA in inflamed dental pulp specimens from japanese Children and adolescents. J. Med. Microbiol. 2015, 64, 117-123. [CrossRef]

10. Nilsson, H.O.; Taneera, J.; Castedal, M.; Glatz, E.; Olsson, R.; Wadström, T. Identification of Helicobacter pylori and other Helicobacter species by PCR, hybridization, and partial DNA sequencing in human liver samples from patients with primary sclerosing cholangitis or primary biliary cirrhosis. J. Clin. Microbiol. 2000, 38, 1072-1076. [CrossRef]

11. Malfertheiner, P.; Megraud, F.; O’Morain, C.A.; Gisbert, J.P.; Kuipers, E.J.; Axon, A.T.; Bazzoli, F.; Gasbarrini, A.; Atherton, J.; Graham, D.Y.; et al. Management of Helicobacter pylori infection-The Maastricht V/Florence Consensus Report. Gut 2016, 66, 6-30. [CrossRef]

12. Wenzhen, Y.; Yumin, L.; Kehu, Y.; Bin, M.; Quanlin, G.; Donghai, W.; Lijuan, Y. Iron deficiency anemia in Helicobacter pylori infection: Meta-analysis of randomized controlled trials. Scand. J. Gastroenterol. 2010, 45, 665-676. [CrossRef]

13. Bai, Y.; Wang, Z.; Bai, X.; Yu, Z.; Cao, L.; Zhang, W.; Ruan, C. Cross-reaction of antibody against Helicobacter pylori urease B with platelet glycoprotein IIIa and its significance in the pathogenesis of immune thrombocytopenic purpura. Int. J. Hematol. 2009, 89, 142-149. [CrossRef] [PubMed]

14. Akcam, M.; Ozdem, S.; Yilmaz, A.; Gultekin, M.; Artan, R. Serum ferritin, vitamin B12, folate, and zinc levels in children infected with Helicobacter pylori. Dig. Dis. Sci. 2007, 52, 405-410. [CrossRef] [PubMed]

15. Vijayvergiya, R.; Vadivelu, R. Role of Helicobacter pylori infection in pathogenesis of atherosclerosis. World J. Cardiol. 2015, 7, 134-143. [CrossRef] [PubMed]

16. Kim, B.J.; Kim, H.S.; Jang, H.J.; Kim, J.H. Helicobacter pylori Eradication in Idiopathic Thrombocytopenic Purpura: A Meta-Analysis of Randomized Trials. Gastroenterol. Res. Pract. 2018, 2018, 6090878. [CrossRef]

17. Gasbarrini, A.; Gabrielli, M.; Fiore, G.; Candelli, M.; Bartolozzi, F.; De Luca, A.; Cremonini, F.; Franceschi, F.; Di Campli, C.; Armuzzi, A.; et al. Association between Helicobacter pylori cytotoxic type I CagA-positive strains and migraine with aura. Cephalalgia 2000, 20, 561-565. [CrossRef]

18. Yang, X. Relationship between Helicobacter pylori and Rosacea: Review and discussion. BMC Infect. Dis. 2018, 18, 4-9. [CrossRef]

19. Gravina, A.G.; Zagari, R.M.; De Musis, C.; Romano, L.; Loguercio, C.; Romano, M. Helicobacter pylori and extragastric diseases: A review. World J. Gastroenterol. 2018, 24, 3204-3221. [CrossRef]

20. Wong, F.; Rayner-Hartley, E.; Byrne, M.F. Extraintestinal manifestations of Helicobacter pylori: A concise review. World J. Gastroenterol. 2014, 20, 11950-11961. [CrossRef]

21. Franceschi, F.; Covino, M.; Roubaud Baudron, C. Review: Helicobacter pylori and extragastric diseases. Helicobacter 2019, 24, e12636. [CrossRef]

22. Rubenstein, J.H.; Inadomi, J.M.; Scheiman, J.; Schoenfeld, P.; Appelman, H.; Zhang, M.; Metko, V.; Kao, J.Y. Association between helicobacter pylori and Barrett's esophagus, erosive esophagitis, and gastroesophageal reflux symptoms. Clin. Gastroenterol. Hepatol. 2014, 12, 239-245. [CrossRef] [PubMed]

23. Zhang, H.; Dai, Y.; Liu, Y.; Wu, T.; Li, J.; Wang, X.; Wang, W. Helicobacter pylori colonization protects against chronic experimental colitis by regulating Th17/Treg Balance. Inflamm. Bowel Dis. 2018, 24, 1481-1492. [CrossRef] [PubMed]

24. Lin, K.D.; Chiu, G.F.; Waljee, A.K.; Owyang, S.Y.; El-Zaatari, M.; Bishu, S.; Grasberger, H.; Zhang, M.; Wu, D.C.; Kao, J.Y. Effects of Anti-Helicobacter pylori Therapy on Incidence of Autoimmune Diseases, Including Inflammatory Bowel Diseases. Clin. Gastroenterol. Hepatol. 2019, 17, 1991-1999. [CrossRef]

25. Schwab, R. Symptomatology and medical treatment of Parkinson's disease. Int. J. Neurol. 1961, 2, 61-75. [PubMed]

26. Strang, R.R. The Association of Gastro-Duodenl Ulceration and Parkinson's Disease. Med. J. Aust. 1965, 51, 842-843. [CrossRef]

27. Szabo, S. Dopamine disorder in duodenal ulceration. Lancet 1979, 2, 880-882. [CrossRef]

28. Altschuler, E. Gastric Helicobacter pylori infection as a cause of idiopathic Parkinson disease and non-arteric anterior optic ischemic neuropathy. Med. Hypotheses 1996, 47, 413-414. [CrossRef]

29. Sikiric, P.; Rotkvic, I.; Mise, S.; Petek, M.; Rucman, R.; Seiwerth, S.; Zjacic-Rotkvic, V.; Duvnjak, M.; Jagic, V.; Suchanek, E.; et al. Dopamine agonists prevent duodenal ulcer relapse-A comparative study with famotidine and cimetidine. Dig. Dis. Sci. 1991, 36, 905-910. [CrossRef]

30. Dobbs, S.M.; Dobbs, R.J.; Weller, C.; Charlett, A. Link between Helicobacter pylori infection and idiopathic parkinsonism. Med. Hypotheses 2000, 55, 93-98. [CrossRef] 
31. Egeberg, A.; Hansen, P.R.; Gislason, G.H.; Thyssen, J.P. Exploring the Association Between Rosacea and Parkinson Disease. JAMA Neurol. 2016, 73, 529-534. [CrossRef] [PubMed]

32. Fischer, M.; Gemende, I.; Marsch, W.C.; Fischer, P.A. Skin function and skin disorders in Parkinson's disease. J. Neural Transm. 2001, 108, 205-213. [CrossRef] [PubMed]

33. Scher, A.I.; Ross, G.W.; Garcia, M.; Gudmundsson, L.S.; Wagner, A.K. Midlife migraine and late-life parkinsonism. Neurology 2014, 83, 1246-1252. [CrossRef] [PubMed]

34. Drumm, B.; Perez-Perez, G.I.; Blaser, M.J.; Sherman, P.M. Intrafamilial Clustering of Helicobacter pylori Infection. N. Engl. J. Med. 1990, 322, 359-363. [CrossRef]

35. Charlett, A.; Dobbs, R.; Dobbs, S.; Weller, C.; Brady, P.; DW, P. Parkinsonism: Siblings share Helicobacter pylori seropositivity and facets of syndrome. Acta Neurol. Scand. 1999, 99, 26-35. [CrossRef]

36. Shamseer, L.; Moher, D.; Clarke, M.; Ghersi, D.; Liberati, A.; Petticrew, M.; Shekelle, P.; Stewart, L.A.; Altman, D.G.; Booth, A.; et al. Preferred reporting items for systematic review and meta-analysis protocols (prisma-p) 2015: Elaboration and explanation. BMJ 2015, 349, g7647. [CrossRef]

37. Goetz, C.G.; Fahn, S.; Martinez-Martin, P.; Poewe, W.; Sampaio, C.; Stebbins, G.T.; Stern, M.B.; Tilley, B.C.; Dodel, R.; Dubois, B.; et al. Movement Disorder Society-sponsored revision of the Unified Parkinson's Disease Rating Scale (MDS-UPDRS): Process, format, and clinimetric testing plan. Mov. Disord. 2007, 22, 41-47. [CrossRef]

38. Webster, D.D. Critical analysis of the disability in Parkinson's disease. Mod. Treat. 1968, 5, $257-282$.

39. Peto, V.; Jenkinson, C.; Fitzpatrick, R.; Greenhall, R. The development and validation of a short measure of functioning and well being for individuals with Parkinson's disease. Qual. Life Res. 1995, 4, 241-248. [CrossRef]

40. Hoehn, M.M.; Yahr, M.D. Parkinsonism: Onset, progression, and mortality. Neurology 1967, 17, 427-442. [CrossRef]

41. Schwab, R.; England, A.G. Projection technique for evaluating surgery in Parkinson's disease. In Third Symposium on Parkinson's Disease; Gillingham, F.J., Donaldson, M.L., Eds.; Churchill Livingstone: Edinburgh, UK, 1969; pp. 152-157.

42. Kirollos, C.; O’neill, C.J.A.; Dobbs, R.J.; Charlett, A.; Bowes, S.G.; Weller, C.; Purkiss, A.G.; Hunt, W.B.; Dobbs, S.M. Quantification of the cardinal signs of parkinsonism and of associated disability in spouses of sufferers. Age Ageing 1993, 22, 20-26. [CrossRef] [PubMed]

43. OCEBM Levels of Evidence Working Group. The Oxford 2011 Levels of Evidence; Centre for Evidence-Based Medicine: Oxford, UK, 2011.

44. Higgins, J.P.T.; Altman, D.G.; Gøtzsche, P.C.; Jüni, P.; Moher, D.; Oxman, A.D.; Savović, J.; Schulz, K.F.; Weeks, L.; Sterne, J.A.C. The Cochrane Collaboration's tool for assessing risk of bias in randomised trials. BMJ 2011, 343, d5928. [CrossRef] [PubMed]

45. Bjarnason, I.T.; Charlett, A.; Dobbs, R.J.; Dobbs, S.M.; Ibrahim, M.A.A.; Kerwin, R.W.; Mahler, R.F.; Oxlade, N.L.; Peterson, D.W.; Plant, J.M.; et al. Role of chronic infection and inflammation in the gastrointestinal tract in the etiology and pathogenesis of idiopathic parkinsonism. Part 2: Response of facets of clinical idiopathic parkinsonism to Helicobocter pylori eradication. A randomized, double-b. Helicobacter 2005, 10, 276-287. [CrossRef] [PubMed]

46. Dobbs, S.M.; Dobbs, R.J.; Weller, C.; Charlett, A.; Bjarnason, I.; Lawson, A.; Letley, D.; Harbin, L.; Price, A.; Ibrahim, M.; et al. Differential Effect of Helicobacter pylori Eradication on Time-Trends in Brady/Hypokinesia and Rigidity in Idiopathic Parkinsonism Report on Completion of a Randomized, Double-Blind, Placebo-Controlled Efficacy Study. Helicobacter 2010, 15, 279-294. [CrossRef] [PubMed]

47. Pierantozzi, M.; Pietroiusti, A.; Brusa, L.; Galati, S.; Stefani, A.; Lunardi, G.; Fedele, E.; Sancesario, G.; Bernardi, G.; Bergamaschi, A.; et al. Helicobacter pylori eradication and 1-dopa absorption in patients with PD and motor fluctuations. Neurology 2006, 66, 1824-1829. [CrossRef] [PubMed]

48. Pierantozzi, M.; Pietroiusti, A.; Sancesario, G.; Lunardi, G.; Fedele, E.; Giacomini, P.; Frasca, S.; Galante, A.; Marciani, M.G.; Stanzione, P. Reduced L-dopa absorption and increased clinical fluctuations in Helicobacter pylori-infected Parkinson's disease patients. Neurol. Sci. 2001, 22, 89-91. [CrossRef]

49. Lee, W.Y.; Yoon, W.T.; Shin, H.Y.; Jeon, S.H.; Rhee, P.L. Helicobacter pylori infection and motor fluctuations in patients with Parkinson's disease. Mov. Disord. 2008, 23, 1696-1700. [CrossRef] 
50. Hashim, H.; Azmin, S.; Razlan, H.; Yahya, N.W.; Tan, H.J.; Manaf, M.R.A.; Ibrahim, N.M. Eradication of Helicobacter pylori infection improves levodopa action, clinical symptoms and quality of life in patients with parkinson's disease. PLoS ONE 2014, 9, e112330. [CrossRef]

51. Liu, H.; Su, W.; Li, S.; Du, W.; Ma, X.; Jin, Y.; Li, K.; Chen, H. Eradication of Helicobacter pylori infection might improve clinical status of patients with Parkinson's disease, especially on bradykinesia. Clin. Neurol. Neurosurg. 2017, 160, 101-104. [CrossRef]

52. Weller, C.; Charlett, A.; Oxlade, N.L.; Dobbs, S.M.; Dobbs, R.J.; Peterson, D.W.; Bjarnason, I.T. Role of chronic infection and inflammation in the gastrointestinal tract in the etiology and pathogenesis of idiopathic parkinsonism. Part 3: Predicted probability and gradients of severity of idiopathic parkinsonism based on $\mathrm{H}$. pylori antibody profile. Helicobacter 2005, 10, 288-297. [CrossRef]

53. Narożańska, E.; Białecka, M.; Adamiak-Giera, U.; Gawrońska-Szklarz, B.; Sołtan, W.; Schinwelski, M.; Robowski, P.; Madaliński, M.H.; Sławek, J. Pharmacokinetics of Levodopa in Patients With Parkinson Disease and Motor Fluctuations Depending on the Presence of Helicobacter pylori Infection. Clin. Neuropharmacol. 2014, 37, 96-99. [CrossRef] [PubMed]

54. Bu, X.-L.; Wang, X.; Xiang, Y.; Shen, L.L.; Wang, Q.H.; Liu, Y.H.; Jiao, S.S.; Wang, Y.J.Y.R.; Cao, H.Y.; Yi, X.; et al. The association between infectious burden and Parkinson's disease: Acase-control study. Park. Relat. Disord. 2015, 21, 877-881. [CrossRef] [PubMed]

55. Tan, A.H.; Mahadeva, S.; Marras, C.; Thalha, A.M.; Kiew, C.K.; Yeat, C.M.; Ng, S.W.; Ang, S.P.; Chow, S.K.; Loke, M.F.; et al. Helicobacter pylori infection is associated with worse severity of Parkinson's disease. Parkinsonism Relat. Disord. 2015, 21, 221-225. [CrossRef] [PubMed]

56. Esmael, A.; El-Sherif, M.; Shabana, H.R.; Elazzouny, A.A. Helicobacter pylori infection in Egyptians with Parkinson's disease: Incidence and the effect on motor fluctuation and response to levodopa. Egypt. J. Neurol. Psychiatry Neurosurg. 2016, 53, 84-88.

57. Roshan, T.B.; Bihani, A.; Seyed, R.H.; Bagherzade, M.; Saadat, P.; Zamani, M. The Association between Helicobacter Pylori Infection and Parkinson's Disease: A Case-Control Study. J. Clin. Diagn. Res. 2018, 12, 5-8. [CrossRef]

58. Dobbs, R.J.; Dobbs, S.M.; Weller, C.; Bjarnason, I.T.; Oxlade, N.L.; Charlett, A.; Al-janabi, M.A.; Kerwin, R.W.; Mahler, R.F.; Price, A.B. Role of Chronic Infection and Inflammation in the Gastrointestinal ract in the Etiology and Pathogenesis of Idiopathic Parkinsonism. Part 1: Eradication of Helicobacter in the Cachexia of Idiopathi Parkinsonism. Helicobacter 2005, 10, 267-275. [CrossRef]

59. Suwarnalata, G.; Tan, A.H.; Isa, H.; Gudimella, R.; Anwar, A.; Loke, M.F.; Mahadeva, S.; Lim, S.Y.; Vadivelu, J. Augmentation of autoantibodies by Helicobacter pylori in Parkinson's disease patients may be linked to greater severity. PLOS ONE 2016, 11, e0153725. [CrossRef]

60. Fasano, A.; Bove, F.; Gabrielli, M.; Petracca, M.; Zocco, M.A.; Ragazzoni, E.; Barbaro, F.; Piano, C.; Fortuna, S.; Tortora, A.; et al. The role of small intestinal bacterial overgrowth in Parkinson's disease. Mov. Disord. 2013, 28, 1241-1249. [CrossRef]

61. Rahne, K.E.; Tagesson, C.; Nyholm, D. Motor fluctuations and Helicobacter pylori in Parkinson's disease. J. Neurol. 2013, 260, 2974-2980. [CrossRef]

62. Dobbs, R.; Charlett, A.; Dobbs, S.; Weller, C.; Peterson, D. Parkinsonism: Differential age-trend in Helicobacter pylori antibody. Aliment. Pharmacol. Ther. 2000, 14, 1199-1205. [CrossRef]

63. Nielsen, H.H.; Qiu, J.; Friis, S.; Wermuth, L.; Ritz, B. Treatment of Helicobacter pylori infection and risk of Parkinson's Disease in Denmark. Eur. J. Neurol. 2013, 19, 864-869. [CrossRef] [PubMed]

64. Blaecher, C.; Smet, A.; Flahou, B.; Pasmans, F.; Ducatelle, R.; Taylor, D.; Weller, C.; Bjarnason, I.; Charlett, A.; Lawson, A.J.; et al. Significantly higher frequency of Helicobacter suis in patients with idiopathic parkinsonism than in control patients. Aliment. Pharmacol. Ther. 2013, 38, 1347-1353. [CrossRef] [PubMed]

65. Huang, H.K.; Wang, J.H.; Lei, W.Y.; Chen, C.L.; Chang, C.Y.; Liou, L.S. Helicobacter pylori infection is associated with an increased risk of Parkinson's disease: A population-based retrospective cohort study. Park. Relat. Disord. 2018, 47, 26-31. [CrossRef]

66. Dobbs, S.M.; Dobbs, R.J.; Weller, C.; Charlett, A.; Augustin, A.; Taylor, D.; Ibrahim, M.A.A.; Bjarnason, I. Peripheral aetiopathogenic drivers and mediators of Parkinson's disease and co-morbidities: Role of gastrointestinal microbiota. J. Neurovirol. 2016, 22, 22-32. [CrossRef]

67. Rees, K.; Stowe, R.; Patel, S.; Ives, N.; Breen, K.; Clarke, C.E.; Ben-Shlomo, Y. Helicobacter pylori eradication for Parkinson's disease. Cochrane Database Syst. Rev. 2011. [CrossRef] 
68. Shen, X.; Yang, H.; Wu, Y.; Zhang, D.; Jiang, H. Meta-analysis: Association of Helicobacter pylori infection with Parkinson's diseases. Helicobacter 2017, 22, e12398. [CrossRef]

69. Dardiotis, E.; Tsouris, Z.; Mentis, A.-F.A.; Siokas, V.; Michalopoulou, A.; Sokratous, M.; Dastamani, M.; Bogdanos, D.P.; Deretzi, G.; Kountouras, J.H. pylori and Parkinson's disease: Meta-analyses including clinical severity. Clin. Neurol. Neurosurg. 2018, 175, 16-24. [CrossRef]

70. Dobbs, S.M.; Charlett, A.; John Dobbs, R.; Weller, C.; Iguodala, O.; Smee, C.; Lawson, A.J.; Taylor, D.; Bjarnason, I. Antimicrobial surveillance in idiopathic parkinsonism: Indication-specific improvement in hypokinesia following Helicobacter pylori eradication and non-specific effect of antimicrobials for other indications in worsening rigidity. Helicobacter 2013, 18, 187-196. [CrossRef]

71. Dobbs, R.J.; Charlett, A.; Dobbs, S.M.; Weller, C.; A Ibrahim, M.A.A.; Iguodala, O.; Smee, C.; Plant, J.M.; Lawson, A.J.; Taylor, D.; et al. Leukocyte-subset counts in idiopathic parkinsonism provide clues to a pathogenic pathway involving small intestinal bacterial overgrowth. A surveillance study. Gut Pathog. 2012, 4, 1-16. [CrossRef] [PubMed]

72. Augustin, A.D.; Charlett, A.; Weller, C.; Dobbs, S.M.; Taylor, D.; Bjarnason, I.; Dobbs, R.J. Quantifying rigidity of Parkinson's disease in relation to laxative treatment: A service evaluation. Br. J. Clin. Pharmacol. 2016, 82, 441-450. [CrossRef] [PubMed]

73. Pagano, G.; Yousaf, T.; Wilson, H.; Niccolini, F.; Polychronis, S.; Chaudhuri, K.R.; Politis, M. Constipation is not associated with dopamine transporter pathology in early drug-naïve patients with Parkinson's disease. Eur. J. Neurol. 2018, 25, 307-312. [CrossRef] [PubMed]

74. Chen, H.; O’Reilly, E.J.; Schwarzschild, M.A.; Ascherio, A. Peripheral inflammatory biomarkers and risk of Parkinson's disease. Am. J. Epidemiol. 2008, 167, 90-95. [CrossRef] [PubMed]

75. Yuan, X.-Y.; Yan, J.-J.; Yang, Y.-C.; Wu, C.-M.; Hu, Y.; Geng, J.-L. Helicobacter pylori with East Asian-type cagPAI genes is more virulent than strains with Western-type in some cagPAI genes. Braz. J. Microbiol. 2017, 48, 218-224. [CrossRef]

76. Augustin, A.D.; Savio, A.; Nevel, A.; Ellis, R.J.; Weller, C.; Taylor, D.; Tucker, R.M.; Ibrahim, M.A.A.; Bjarnason, I.; Dobbs, S.M.; et al. Helicobacter suis Is Associated With Mortality in Parkinson's Disease. Front. Med. 2019, 6, 188. [CrossRef] [PubMed]

77. Chen, Y.; Segers, S.; Blaser, M.J. Association between Helicobacter pylori and mortality in the NHANES III study. Gut 2013, 62, 1262-1269. [CrossRef] [PubMed]

78. Vermoote, M.; Theo, T.; Vandekerckhove, M.; Flahou, B.; Pasmans, F.; Smet, A.; De Groote, D.; Van Criekinge, W.; Ducatelle, R.; Haesebrouck, F. Genome sequence of Helicobacter suis supports its role in gastric pathology. Vet. Res. 2011, 42. [CrossRef]

79. Wang, T.C.; Fox, J.G. Helicobacter pylori and gastric cancer: Koch's postulates fulfilled? Gastroenterology 1998, 115, 780-783. [CrossRef]

80. Hill, A.B. The Environment and Disease: Association or Causation? Proc. R. Soc. Med. 1965, 58, $295-300$. [CrossRef]

81. Hughes, A.J.; Daniel, S.E.; Kilford, L.; Lees, A.J. Accuracy of clinical diagnosis of idiopathic Parkinson's disease: A clinico-pathological study of 100 cases. J. Neurol. Neurosurg. Psychiatry 1992, 55, 181-184. [CrossRef]

82. Calne, D.B.; Snow, B.J.; Lee, C. Criteria for diagnosing Parkinson's disease. Ann. Neurol. 1992, 32, S125-S127. [CrossRef]

83. Weller, C.; O'Neill, C.; Charlett, A.; Bowes, S.; Purkiss, A.; Nicholson, P.; Dobbs, R.; Dobbs, S. Defining small differences in efficacy between anti-parkinsonian agents using gait analysis: A comparison of two controlled release formulations of levodopa/decarboxylase inhibitor. Br. J. Clin. Pharmacol. 1993, 35, 379-385. [CrossRef] [PubMed]

84. Robertson, D.; Renwick, A.; Wood, N.; Cross, N.; Macklin, B.; Fleming, J.; Waller, D.; George, C. The influence of levodopa on gastric emptying in man. Br. J. Clin. Pharmacol. 1990, 29, 47-53. [CrossRef] [PubMed]

85. Miyaji, H.; Azuma, T.; Ito, S.; Abe, Y.; Ono, H.; Suto, H.; Ito, Y.; Yamazaki, Y.; Kohli, Y.; Kuriyama, M. The effect of Helicobacter pylori eradication therapy on gastric antral myoelectrical activity and gastric emptying in patients with non-ulcer dyspepsia. Aliment. Pharmacol. Ther. 1999, 13, 1473-1480. [CrossRef] [PubMed]

86. Dobbs, R.J.; Dobbs, S.M.; Weller, C.; Charlett, A.; Taylor, D. Time-Lag between Establishing Clinical Pharmacology Principles and Advances in Practice: The Case of Tolerance to Levodopa. J. Pharmacol. Clin. Toxicol. 2017, 5, 1084. 
87. Chase, T.N.; Engber, T.M.; Mouradian, M.M. Contribution of dopaminergic and glutamatergic mechanisms to the pathogenesis of motor response complications in Parkinson's disease. Adv. Neurol. 1996, 69, 497-501.

88. Bowes, S.; Clark, P.; Charlett, A.; O’Neill, C.; Leeman, A.; Weller, C.; Nicholson, P.; Deshmukh, A.; Dobbs, S.; Dobbs, R. Objective outcome criteria in trials of anti-parkinsonian therapy in the elderly: Sensitivity, specificity and reliability of measures of brady- and hypo-kinesia. Br. J. Clin. Pharmacol. 1991, 31, 295-304. [CrossRef]

89. Smyk, D.S.; Koutsoumpas, A.L.; Mytilinaiou, M.G.; Rigopoulou, E.I.; Sakkas, L.I.; Bogdanos, D.P. Helicobacter pylori and autoimmune disease: Cause or bystander. World J. Gastroenterol. 2014, 20, 613-629. [CrossRef]

90. Lehours, P.; Ferrero, R.L. Review: Helicobacter: Inflammation, immunology, and vaccines. Helicobacter 2019, 24, e12644. [CrossRef]

91. Ekström, A.M.; Held, M.; Hansson, L.E.; Engstrand, L.; Nyrén, O. Helicobacter pylori in gastric cancer established by CagA immunoblot as a marker of past infection. Gastroenterology 2001, 121, 784-791. [CrossRef]

(C) 2020 by the authors. Licensee MDPI, Basel, Switzerland. This article is an open access article distributed under the terms and conditions of the Creative Commons Attribution (CC BY) license (http://creativecommons.org/licenses/by/4.0/). 